Article

\title{
Improvement of Alcohol-Poisoning Symptoms in Mice by the Oral Administration of Live Lactobacillus plantarum SN13T Cells
}

\author{
Masafumi Noda ${ }^{1}$, Masafumi Maruyama ${ }^{2}$, Narandalai Danshiitsoodol ${ }^{1}$, Fumiko Higashikawa ${ }^{1}$ \\ and Masanori Sugiyama ${ }^{1, *}$ \\ 1 Department of Probiotic Science for Preventive Medicine, Graduate School of Biomedical and Health \\ Sciences, Hiroshima University, Kasumi 1-2-3, Minami-ku, Hiroshima 734-8551, Japan; \\ bel@hiroshima-u.ac.jp (M.N.); naraa@hiroshima-u.ac.jp (N.D.); fumiko@hiroshima-u.ac.jp (F.H.) \\ 2 Chugoku Jozo Co., Ltd., Sakurao 1-12-1, Hatsukaichi, Hiroshima 738-0004, Japan; \\ maruyama@chugoku-jozo.co.jp \\ * Correspondence: sugi@hiroshima-u.ac.jp; Tel.: +81-82-257-5280
}

Received: 12 February 2020; Accepted: 9 March 2020; Published: 10 March 2020

\begin{abstract}
A clinical study carried out previously by our group has demonstrated that yogurt manufactured with a plant-derived lactic acid bacterium, Lactobacillus plantarum SN13T, significantly reduces the $\gamma$-glutamyl transpeptidase $(\gamma$-GTP) level as a liver-function parameter. In the present study, we show that with the oral administration of live SN13T cells, alcohol-poisoning symptoms in mice are improved, and the condition does not become fatal. However, prior to the simultaneous administration with ethanol, when the cells were heat-killed or sonicated, the improvement was not observed, and almost all of the mice died. In addition, the dysbiosis of the intestinal microbiota observed in the mice administered with ethanol was restored by simultaneous administration with live SN13T cells. Furthermore, by analyzing the metabolites detected in contents from the mouse cecum, it was demonstrated that the increase in nonvolatile putrefactive amines observed in the ethanol-administration group was reduced by simultaneous administration with live SN13T cells. Judging from these results, the lactic acid bacterial cells capable of reaching the living bowels prevent ethanol-induced poisoning and restore the intestinal microbiota.
\end{abstract}

Keywords: alcohol-poisoning symptoms; Lactobacillus plantarum; live lactic acid bacteria

\section{Introduction}

Beer and wine are alcoholic beverages that have been drunk since 3000 and 6000 B.C., respectively [1]. These beverages not only are consumed as "pleasure products" but also have been associated with festive rituals and used for medicinal purposes [2]. However, it is obvious that the abuse of alcohol has a close connection to health problems such as hepatitis, pancreatitis, and alcoholism.

Alcoholic steatohepatitis is a hepatic disease caused by the intake of alcohol for a long time. Almost all of the alcohol absorbed into the human body is metabolized by alcohol dehydrogenase (ADH:EC1.1.1.1), which is present mainly in the liver. The enzyme facilitates the interconversion between alcohols and aldehydes or ketones. Although the biological half-life of acetaldehyde is relatively short, in the case of excessive and chronic alcohol consumption, the carcinogenic metabolite acetaldehyde easily accumulates in the human body and finally causes hepatocellular injury [3,4].

Recent studies have shown that ethanol metabolism leads to the inhibition of fatty acid oxidation, as well as the stimulation of lipogenesis, resulting in hepatic fatty acid overload [5]. Up to $20 \%$ of heavy alcohol drinkers will suffer from the liver cirrhosis [6], which is a late stage of chronic severe 
hepatic inflammation defined as the histological development of "regenerative nodules surrounded by fibrous bands" [7].

Lactic acid bacteria (LAB) are generally considered as "probiotics." The word "probiotics" is defined as "the live microorganisms conferring a health benefit on the host when administered in adequate amounts" [8], and probiotic LAB strains traditionally have been used to manufacture fermented foods. It has been reported that some $\mathrm{LAB}$ cells and fermented foods containing the bacteria have potent health benefits, such as promoting intestinal homeostasis, possessing anti-allergic properties, and preventing and improving obesity [9-16].

The LAB strains are roughly classified into two groups: One is designated as animal-derived LAB and have been widely used to manufacture dairy products, such as yogurt and cheese. Another group is designated as plant-derived LAB, which is isolated from plant sources such as fruits, vegetables, flowers, and medicinal plants. We have previously claimed that, when compared with the animal-derived LAB, the plant-derived ones are superior in tolerance against gastric and bile juice, and immunomodulatory activity [17]. We have already isolated over 1000 LAB strains from many plant sources and stored them in a plant-derived LAB library. We have found that some of the stored LAB strains may be useful for preventive medicine, such as immune modulation, reduction of obesity, and anti-allergy [17-20]. Interestingly, the yogurt manufactured with Lactobacillus $(L b$.) plantarum SN13T stored in the library has been demonstrated through a previous clinical study to significantly reduce the serum $\gamma$-glutamyl transpeptidase $(\gamma$-GTP) value [21].

The aim of this study is to find another healthcare function of the SN13T strain through animal experimentation using mice fed with ethanol. When live SN13T cells were orally administered to mice fed with a diet containing ethanol, death caused by the intake of ethanol was completely avoided, demonstrating that recovery from alcohol-poisoning symptoms in mice was observed only with oral administration of the live cells. In this study, we also demonstrate fluctuations in the intestinal microbiota and metabolites, which are restored by administration of the live cells.

\section{Results}

\subsection{Health Benefit of Live SN13T Cells against the Alcohol-Poisoning Symptom in Mice}

Figure 1 shows the survival curves of mice reared using an ethanol-containing diet supplemented with or without SN13T cells. When compared with a group without the intake of ethanol, the cumulative survival rate of the ethanol-intake group without the added live SN13T cells was significantly decreased $(p<0.001$, Figure 1a), and the mice died within 17 days. However, with simultaneous administration of live SN13T cells, the survival rate of the mice did not decrease when compared with a group receiving no alcohol (Figure 1b), strictly, although only one mouse died. In contrast, the survival rate $(p=0.362$, Figure 1c) was not improved under supplementation with the heat-killed cells, indicating that there is an obvious difference between the live and heat-killed cell groups $(p<0.001$, Figure 1d). Thus, the administration of live SN13T cells is essential for improving alcohol-poisoning symptoms. 
(a)

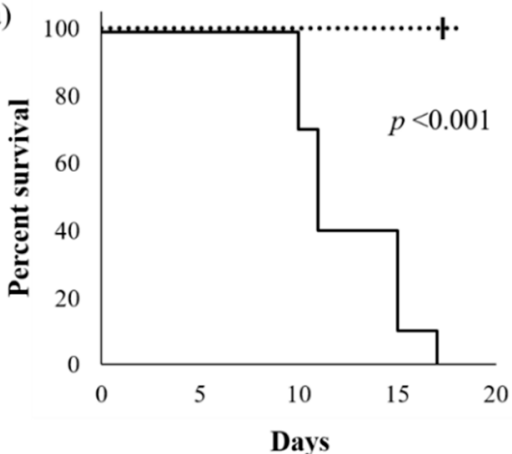

(c)

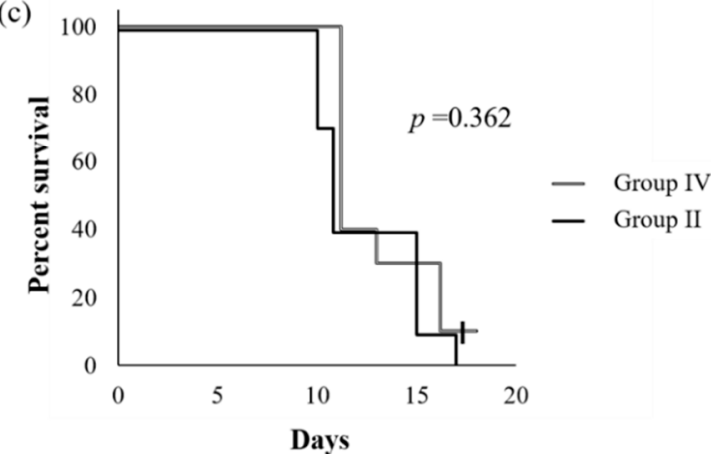

(b)

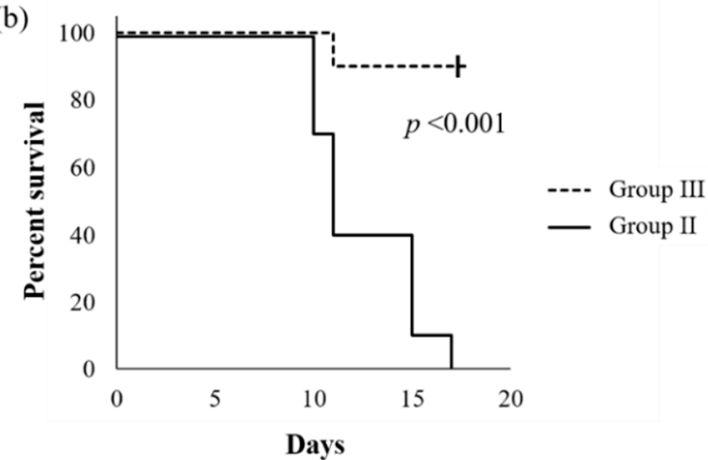

(d)

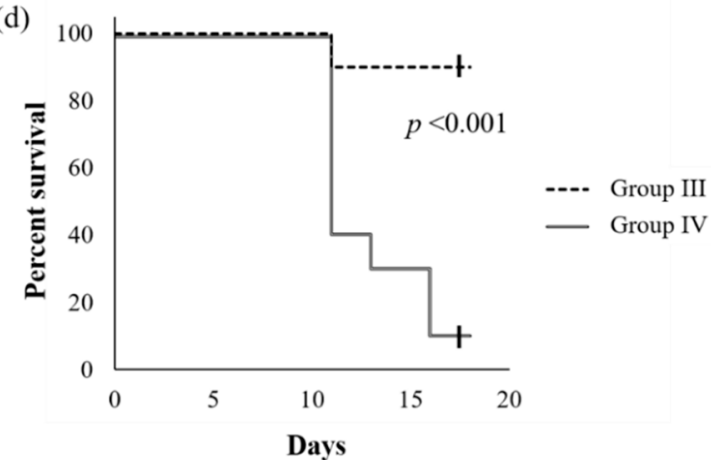

Figure 1. The Kaplan-Meier survival curves of C57BL/6J mice fed an ethanol-containing diet with or without the addition of live SN13T cells. The group fed without ethanol was also compared. The $p$-values were calculated using the log-rank test. Group I, which was fed only an L10015 diet without the administration of ethanol; group II, which was fed an L10016 diet with ethanol; groups III and IV, which were fed with the simultaneous administration of ethanol and the live or heat-killed SN13T cells, respectively, in the L10016 diet. Each graph shows the comparison of survival rate (\%) between Groups I and II (a), II and III (b), II and IV (c), and III and IV (d), respectively.

\subsection{Fecal Microbiota Analysis Using the Terminal Restriction Fragment Length Polymorphism (T-RFLP) Method}

To evaluate the lethal effect of ethanol and the change in intestinal flora in mice due to the SN13T cells, the intestinal microbiota in feces collected from each group with or without the SN13T cells was analyzed using the T-RFLP method with partial 16S rDNA (Figure 2). When compared with a control group (group I) without the administered ethanol, the relative abundance ratios of the genus Bacteroides and the order Lactobacillales were remarkably increased and decreased, respectively, by the administration of ethanol (group II). Specifically, the genus Bacteroides was observed to occupy half of the intestinal flora in group II. The changes in Bacteroides and Lactobacillales were notably and slightly repressed by the ethanol-containing diet supplemented with live and heat-killed cell groups (groups III and IV), respectively. In addition, the intestinal bacteria, which cannot be classified via the T-RFLP method, were significantly increased in group II. 


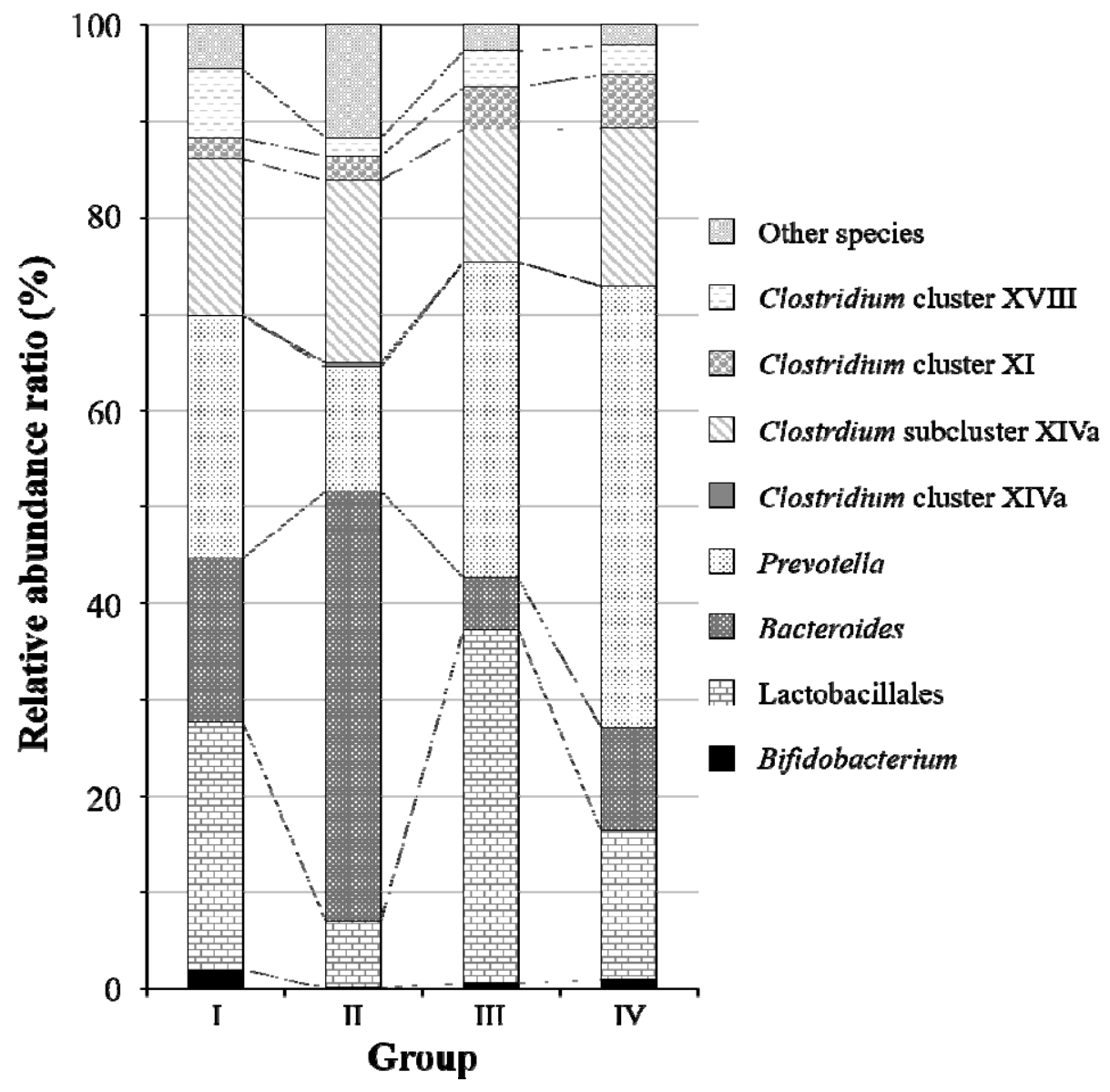

Figure 2. Differences in the fecal microbiota composition in mice after the experimental period as determined via the terminal restriction fragment length polymorphism (T-RFLP) analysis. The experimental content of each group is the same as that in Figure 1.

Based on the T-RFLP analysis, it is suggested that (1) ethanol caused the intestinal microbiota disorder, and (2) supplementation with live SN13T cells improves the microbiota disorder in mice. Although live SN13T cells reach the intestine alive and reduce the lethal function of ethanol, further information is needed to clarify the relationship between lethality and the mechanism of lethality prevention observed only with the live SN13T cells.

\subsection{Intestinal Microbiota Analysis}

In the present study, we also analyzed the intestinal microbiota of mice fed an ethanol-containing diet supplemented with or without live SN13T cells. As shown in Figure 3, the intestinal microbiota from mice fed the ethanol-containing diet without bacterial cells (group B) was obviously different from that of mice fed a diet supplemented without both ethanol and the bacterial cells (group A). Specifically, with respect to the group B microbiota in the small intestine, Enterococcaceae was extremely increased, and this phenomenon was also observed in the cecum and large intestine. In the cecum, the ratios of Akkermansia, Allobaculum, and Paraprevotellaceae were remarkably decreased by the administration of ethanol, but these phenomena disappeared with the simultaneous administration with live SN13T cells. On the other hand, although the ratio of an RF32 order was notable increased in group B, interestingly, when live SN13T cells were administered simultaneously with ethanol, the population of RF32 was clearly decreased, as summarized in Table 1. Additionally, the administration of ethanol was found to increase the aspartate transaminase (AST) and alanine aminotransferase (ALT) levels in serum, whereas both levels were reduced by the simultaneous administration of live SN13T cells (Figure 4). 

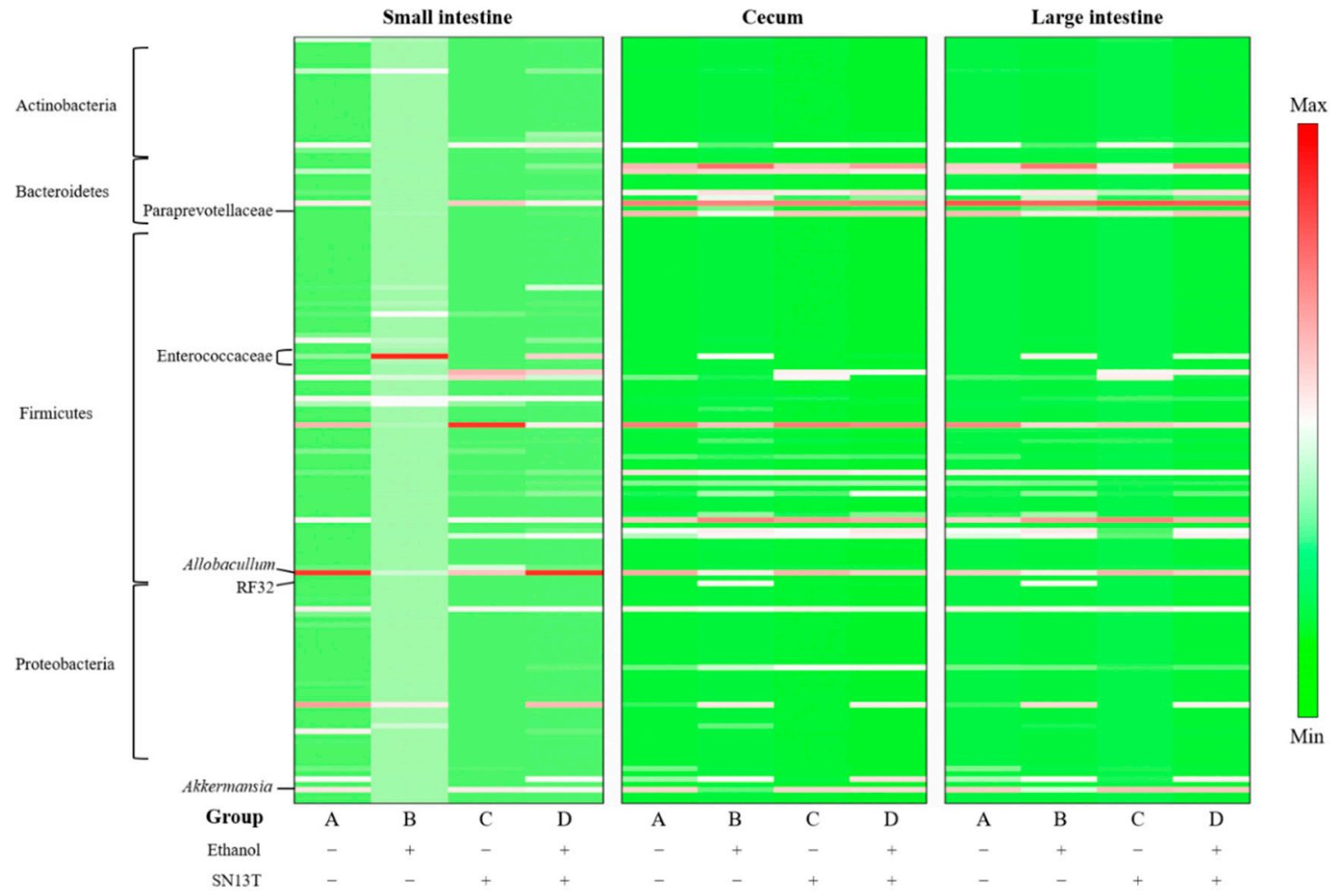

Figure 3. The microbiota in the small intestine, cecum, and large intestine collected from C57BL/6J mice. Prior to the administration of ethanol, the mice were kept for one week using the L10015 diet supplemented with (groups C and D) or without (groups A and B) live SN13T cells. After one week, the L10015 diet was changed to an L10016 diet in groups B and D. The intestinal bacteria were determined using the $\mathrm{V} 3-\mathrm{V} 4$ region in $16 \mathrm{~S}$ rDNA and indicated by the standardized relative abundance ratio. Denser green and red indicate lower and higher amounts, respectively.
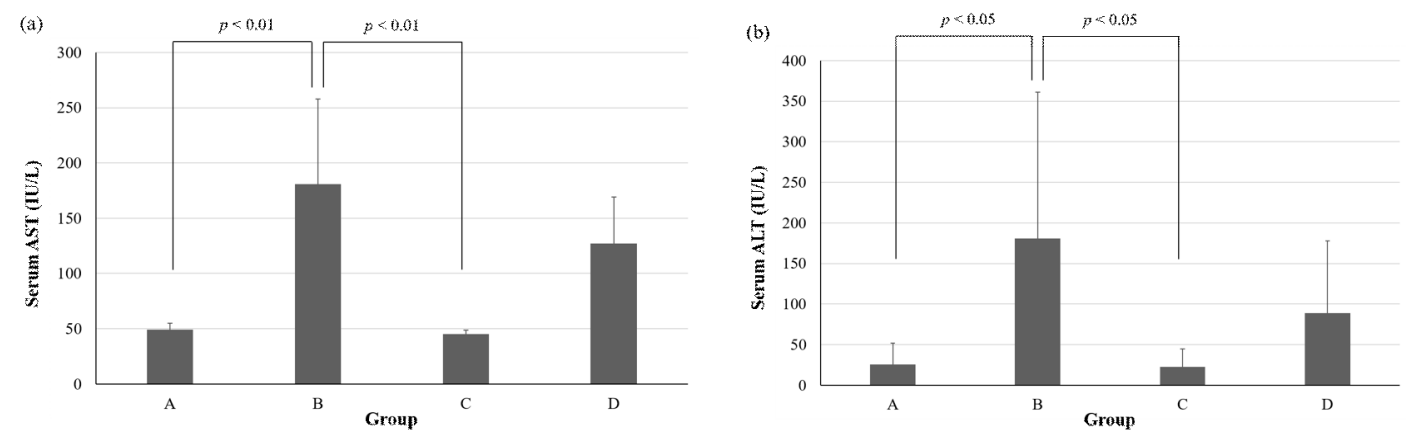

Figure 4. The difference in the serum the aspartate transaminase (AST) (a) and alanine aminotransferase (ALT) (b) levels of mice with the simultaneous administration of ethanol with or without live SN13T cells. The values are indicated as the mean \pm SD. Statistical analysis was performed using the Tukey-Kramer multiple comparisons test. The experimental content of each group is the same as that in Figure 3. 
Table 1. The summary of changes in intestinal microbiota composition.

\begin{tabular}{|c|c|c|c|c|c|}
\hline Part of Intestine/Alteration & Phylum & Class & Order & Family & Genus \\
\hline \multicolumn{6}{|l|}{ Small intestine } \\
\hline & & $\underset{*, 3}{\text { Epsilonproteobacteria }}$ & Bacillales & Propionibacteriaceae * & Propionibacterium * \\
\hline Increased $^{1}$ & & & $\begin{array}{c}\text { Lactobacillales * } \\
\text { Campylobacterales * }\end{array}$ & $\begin{array}{l}\text { Paraprevotellaceae * } \\
\text { Staphylococcaceae * } \\
\text { Enterococcaceae * } \\
\text { Campylobacteraceae * }\end{array}$ & $\begin{array}{c}\text { Staphylococcus * } \\
\text { Facklamia * } \\
\text { Enterococcus } \\
\text { Arcobacter } \\
\text { Proteus } \\
\text { * }\end{array}$ \\
\hline Decreased $^{2}$ & $\begin{array}{c}\text { Bacteroidetes * } \\
\text { Cyanobacteria } \\
\text { Proteobacteria * } \\
\text { TM7 * } \\
\text { Tenericutes * } \\
\text { Verrucomicrobia * }\end{array}$ & $\begin{array}{c}\text { Coriobacteriia * } \\
\text { Bacteroidiia * } \\
\text { Chloroplast } \\
\text { Clostridia * } \\
\text { Erysipelotrichi * } \\
\text { Alphaproteobacteria * } \\
\text { Betaproteobacteria * } \\
\text { Deltaproteobacteria * } \\
\text { TM7-3 * } \\
\text { Mollicutes * } \\
\text { Verrucomicrobiae * }\end{array}$ & $\begin{array}{l}\text { Coriobacteriales * } \\
\text { Bacteroidales * } \\
\text { Streptophyta } \\
\text { Clostridiales * } \\
\text { Erysipelotrichales * } \\
\text { Rhizobiales } \\
\text { Burkholderiales * } \\
\text { Desulfovibrionales * } \\
\text { Spirobacillales } \\
\text { Pseudomonadales * } \\
\text { CW040* } \\
\text { RF39* } \\
\text { Verrucomicrobiales * }\end{array}$ & $\begin{array}{c}\text { Coriobacteriaceae * } \\
\text { Porphyromonadaceae * } \\
\text { S24-7* } \\
\text { Lactobacillaceae * } \\
\text { Clostridiaceae } \\
\text { Lachnospiraceae * } \\
\text { Ruminococcaceae * } \\
\text { Erysipelotrichaceae * } \\
\text { Methylobacteriaceae } \\
\text { Alcaligenaceae * } \\
\text { Desulfovibrionaceae * } \\
\text { F16 * } \\
\text { Verrucomicrobiaceae * }\end{array}$ & $\begin{array}{l}\text { Adlercreutzia * } \\
\text { Parabacteroides * } \\
\text { Lactobacillus } \\
\text { Clostridium } \\
\text { Coprococcus * } \\
\text { Allobaculum * } \\
\text { Sutterella * } \\
\text { Bilophila * } \\
\text { Akkermansia * }\end{array}$ \\
\hline \multicolumn{6}{|l|}{ Cecum } \\
\hline Increased & & Gammaproteobacteria & $\begin{array}{c}\text { Bacillales } \\
\text { Turicibacterales * } \\
\text { RF32* } \\
\text { Rhodocyclales } \\
\text { Enterobacteriales }\end{array}$ & $\begin{array}{c}\text { Bifidobacteriaceae } \\
\text { Staphylococcaceae * } \\
\text { Enterococcaceae * } \\
\text { Turicibacteraceae * } \\
\text { Oxalobacteraceae * } \\
\text { Rhodocyclaceae } \\
\text { Enterobacteriaceae }\end{array}$ & $\begin{array}{l}\text { Bifidobacterium } \\
\text { Jeotgalicoccus * } \\
\text { Staphylococcus * } \\
\text { Enterococcus } \\
\text { Turicibacter * } \\
\text { Anaerotruncus * } \\
\text { Anaerovorax } \\
\text { Peptoniphilus * } \\
\text { Ralstonia * } \\
\text { Zoogloea * } \\
\text { Proteus * }\end{array}$ \\
\hline
\end{tabular}


Table 1. Cont.

\begin{tabular}{|c|c|c|c|c|c|}
\hline Part of Intestine/Alteration & Phylum & Class & Order & Family & Genus \\
\hline Decreased & Verrucomicrobia & Verrucomicrobiae * & $\begin{array}{c}\text { Rhizobiales } \\
\text { Verrucomicrobiales * }\end{array}$ & $\begin{array}{c}\text { Prevotellaceae * } \\
\text { Bradyrhizobiaceae } \\
\text { Verrucomicrobiaceae * }\end{array}$ & $\begin{array}{l}\text { Clostridium * } \\
\text { Akkermansia }^{*}\end{array}$ \\
\hline \multicolumn{6}{|l|}{ Large intestine } \\
\hline Increased & & $\begin{array}{l}\text { Alphaproteobacteria * } \\
\text { Gammaproteobacteria }\end{array}$ & $\begin{array}{l}\text { Bifidobacteriales } \\
\text { Bacillales * } \\
\text { Turicibacterales * } \\
\text { Enterobacteriales }\end{array}$ & $\begin{array}{l}\text { Bifidobacteriaceae } \\
\text { Staphylococcaceae * } \\
\text { Enterococcaceae * } \\
\text { Turicibacteraceae * } \\
\text { Tissierellaceae * } \\
\text { Enterobacteriaceae }\end{array}$ & $\begin{array}{c}\text { Bifidobacterium } \\
\text { AF12 } \\
\text { Jeotgalicoccus } \\
\text { Staphylococcus * } \\
\text { Facklamia * } \\
\text { Enterococcus * } \\
\text { Turicibacter * } \\
\text { Anaerotruncus * } \\
\text { Finegoldia } \\
\text { Enterobacter } \\
\text { Proteus * }\end{array}$ \\
\hline Decreased & Verrucomicrobia & Verrucomicrobiae * & Verrucomicrobiales * & $\begin{array}{c}\text { Prevotellaceae } \\
\text { Eubacteriaceae } \\
\text { Verrucomicrobiaceae * }\end{array}$ & $\begin{array}{c}\text { Anaerofustis } \\
\text { Akkermansia * }\end{array}$ \\
\hline
\end{tabular}




\subsection{Analysis of Metabolites in the Cecum}

The heatmap obtained from hierarchical cluster analysis (HCA) shows that the metabolite profiles in the cecum were clearly different between ethanol-fed and nonethanol-fed groups (Figure 5). In total, 380 compounds were annotated as metabolites, and 17 of them were found to be increased by the intake of ethanol: Pyruvic acid, propionic acid, 1,3-diaminopropane, stearoyl ethanolamide, $5 \alpha$-pregnan- $3 \alpha$-ol-20-one, cadaverine, isobutyric acid, butyric acid, $N$-acetylglutamic acid, $o$-hydroxybenzoic acid, tyramine, $N^{1}, N^{8}$-diacetylspermidine, isovaleric acid, valeric acid, isopropanolamine, 2-hydroxy-4-methylvaleric acid, and 2-oxoglutaric acid (Table 2). On the other hand, amino acids were decreased by the administration of ethanol (group B), and the changes did not fully recover. The metabolite analysis shows that some compounds were reduced in group B but not in group D. The detailed HCA result is shown in Supplementary Table S1.

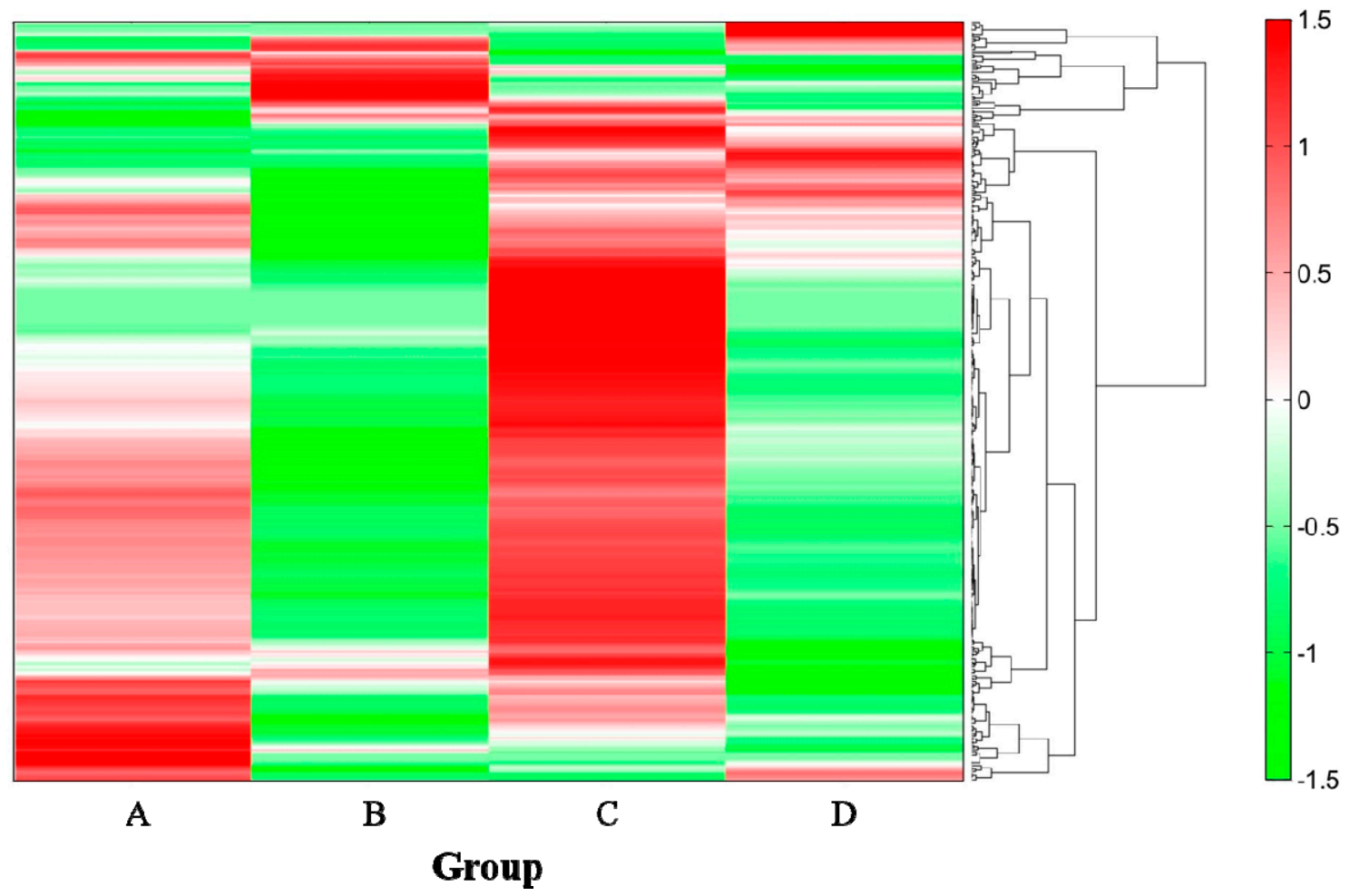

Figure 5. The hierarchical cluster analysis (HCA) of the mouse cecum metabolites. Denser green and red indicate low and high concentrations of metabolites, respectively. The dendrogram depicts the unweighted pair-group method of analysis (UGPMA) based on a standardized relative area of detected compounds. The experimental content of each group is the same as that in Figure 3.

Table 2. Differences of standardized relative area in metabolites in the cecum samples isolated from each mice group.

\begin{tabular}{ccccc}
\hline \multirow{2}{*}{ Compound Name } & \multicolumn{4}{c}{ Group (Ethanol/SN13T) } \\
\cline { 2 - 5 } & $\mathbf{A ~ ( - / - )}$ & $\mathbf{B ~ ( + / - )}$ & $\mathbf{C ~ ( - / + )}$ & $\mathbf{D}(+/+)$ \\
\hline Pyruvic acid & 0.133 & 0.913 & 0.372 & -1.418 \\
Propionic acid & 0.141 & 1.139 & 0.017 & -1.297 \\
1,3-Diaminopropane & -0.338 & 1.197 & 0.307 & -1.166 \\
Stearoyl ethanolamide & -0.461 & 1.238 & 0.302 & -1.079 \\
5 $\alpha$-Pregnan-3 $\alpha$-ol-20-one & 0.190 & 1.333 & -0.642 & -0.880 \\
Cadaverine & 0.218 & 1.326 & -0.772 & -0.772 \\
Isobutyric acid, Butyric acid & 0.018 & 1.397 & -0.859 & -0.557 \\
\hline
\end{tabular}


Table 2. Cont.

\begin{tabular}{|c|c|c|c|c|}
\hline \multirow{2}{*}{ Compound Name } & \multicolumn{4}{|c|}{ Group (Ethanol/SN13T) } \\
\hline & A (-/-) & B (+/-) & $C(-/+)$ & $\mathrm{D}(+/+)$ \\
\hline$N$-Acetylglutamic acid & -0.943 & 1.386 & -0.434 & -0.009 \\
\hline$o$-Hydroxybenzoic acid & -0.610 & 1.490 & -0.541 & -0.339 \\
\hline Tyramine & -0.500 & 1.500 & -0.500 & -0.500 \\
\hline$N^{1}, N^{8}$-Diacetylspermidine & -0.195 & 1.440 & -0.383 & -0.861 \\
\hline Isovaleric acid, Valeric acid & -0.356 & 1.466 & -0.323 & -0.787 \\
\hline Isopropanolamine & -0.642 & 1.455 & -0.141 & -0.672 \\
\hline 2-Hydroxy-4-methylvaleric acid & -0.748 & 1.367 & 0.126 & -0.745 \\
\hline 2-Oxoglutaric acid & -0.878 & 1.189 & 0.464 & -0.775 \\
\hline Glycine (Gly) & 0.635 & -1.190 & 0.994 & -0.439 \\
\hline Alanine (Ala) & 0.511 & -0.990 & 1.146 & -0.667 \\
\hline Valine (Val) & 0.683 & -1.098 & 0.996 & -0.581 \\
\hline Leucine (Leu) & 0.573 & -1.045 & 1.093 & -0.621 \\
\hline Isoleucine (Ilo) & 0.755 & -1.053 & 0.948 & -0.649 \\
\hline Methionine (Met) & 0.603 & -0.990 & 1.083 & -0.696 \\
\hline Proline (Pro) & 0.546 & -1.223 & 1.037 & -0.360 \\
\hline Phenylalanine (Phe) & 0.566 & -1.016 & 1.104 & -0.655 \\
\hline Tryptophan (Try) & 0.569 & -0.929 & 1.115 & -0.755 \\
\hline Serine (Ser) & 0.602 & -1.158 & 1.034 & -0.478 \\
\hline Threonine (Thr) & 0.520 & -1.097 & 1.113 & -0.537 \\
\hline Tyrosine (Tyr) & 0.616 & -1.068 & 1.056 & -0.604 \\
\hline Cystine & 1.113 & -0.984 & 0.562 & -0.691 \\
\hline Arginine (Arg) & 0.544 & -0.972 & 1.127 & -0.699 \\
\hline Histidine (His) & 0.570 & -0.891 & 1.117 & -0.796 \\
\hline Lysine (Lys) & 0.530 & -1.003 & 1.131 & -0.659 \\
\hline Asparagine (Asn) & 0.383 & -0.839 & 1.239 & -0.783 \\
\hline Glutamine (Gln) & 0.353 & -0.886 & 1.253 & -0.720 \\
\hline Asparatic acid (Asp) & 0.600 & -1.177 & 1.026 & -0.449 \\
\hline Glutamic acid (Glu) & 0.701 & -1.059 & 0.993 & -0.634 \\
\hline
\end{tabular}

\section{Discussion}

$\gamma$-GTP (E.C. 2.3.2.2) is an enzyme that catalyzes the hydrolysis of $\gamma$-glutamylpeptide and transfers the $\gamma$-glutamyl residue to other peptides and amino acids. The enzyme is induced in a human body that suffers from hepatic and biliary tract diseases. Since the over-induced enzyme flows out from the organs to the blood as a deviation enzyme, the $\gamma$-GTP level in serum is used as a biomarker for hepatocellular injury caused by obesity and alcohol abuse.

In our clinical study carried out previously, we have shown that the oral administration of live SN13T cells reduces the serum $\gamma$-GTP level [21], suggesting that the LAB cells may improve liver function and protect against alcoholic disorder. Since the C57BL/6J mice have been shown to be useful to investigate the function of alcohol and narcotics, including morphine in previous studies [22-25], we used the same model of mice to evaluate the toxic effect of alcohol.

As described in a report from the Food and Agriculture Organization of the United Nations (FAO) Nutrition Meeting [26], when mice were continuously fed with $0.8 \%-20 \%$ ethanol, their mortality rate increased in proportion to the ethanol concentration. Acute and high ethanol consumption disrupts the intestinal mucosal barrier and eases the flow of harmful compounds, such as endotoxins, into the body [27]. As a result, hepatic disorder followed by sepsis may induce the invasion of intestinal bacteria into the body [27-31]. These reports support that the death observed in mice fed with ethanol may be due to the dysfunction of the intestinal barrier rather than the alcoholic hepatic disorder. The result obtained in the present mice study reveals that the oral administration of live SN13T cells prevents ethanol-induced poisoning and restores the intestinal microbiota (Figures 1 and 2). 
In the microbiota and metabolite analyses, live SN13T cells were administered to the mice prior to ethanol feeding to enhance the preventive effect. Furthermore, to avoid a failure in collecting fresh blood and tissues by sudden mouse death, the mice keeping was terminated when the first death was observed in the ethanol-diet group. This experimental plan allowed us to compare the serum AST and ALT levels in each group. As shown in Figure 4, it was confirmed that live SN13T cells reduce both levels.

Intestinal microbiota analysis in the present study showed that the significant dysbiosis in the mouse small intestine is caused by the intake of ethanol; specifically, the family Enterococcaceae is drastically increased. On the other hand, the dysbiosis of the intestinal microbiota in the cecum and large intestine was not observed, suggesting that the intestinal microbiota has been buffered in the passage of the cecum, because a branched cecum appendix is an apparent safe niche for intestinal bacteria. Thus, the appendix maintains the microbial biofilm composed of indigenous bacteria [32,33]. Considering these results, the microbiota recovery effect observed in the cecum is likely to be important to protect the large intestine from some undesirable bacteria.

Although the significance of the cecum has not been completely elucidated, however, there are significant reports regarding the cecum: That is, surgical removal of the appendix in mice induces the reduction of immunoglobulin A (IgA)-secreting cells in the large intestine and reduces alteration of the fecal microbiota composition [34]. These results indicate that a lymphoid organ in the appendix is necessary to generate and migrate IgA-secreting cells and to regulate the intestinal microbiota. In addition, a comparison study of 533 mammalian species showed that there is a relationship between appendix presence and the concentration of cecal lymphoid tissue [35]. Therefore, the cecum seems to be important for maintaining not only the microbiota balance but also the immune system.

It is still unclear why the ratio of some bacteria, including Enterococcaceae and Allobaculum spp., was remarkably changed by the intake of ethanol. It is necessary to determine how these bacteria function or communicate to some microorganisms originally present in the intestine. However, Akkermansia spp. and a putative order of RF32 have been shown to be involved in the intestinal inflammatory response. The genus Akkermansia consists of two species, Akkermansia (A.) glycaniphila and A. muciniphila. The latter species is an anaerobic intestinal commensal bacterium and occupies $1 \%-4 \%$ of the fecal microbiota in humans [36,37]. A. muciniphila promotes intestinal barrier function, and the bacterium is rarely present in the intestine of IBD patients [38-40]. Furthermore, it has been shown that patients with alcoholic steatohepatitis exhibit a decreased amount of the bacterial species as compared with healthy persons, and the amount of the species in fecal content was also decreased in ethanol-fed mice [41]. On the other hand, there is an obvious relationship among colonic damage, inflammation, and abundance of the RF32 order [42]. Those reports support our hypothesis that the intake of live SN13T cells restores the inflammation caused by ethanol abuse via changing the intestinal microbiota.

Changes in the cecum components, which have a buffering effect against alteration of the intestinal microbiota, may affect the homeostasis. The metabolite analysis done in the present study showed that putrefactive amines, such as tyramine and cadaverine, were increased in the ethanol-fed group. In addition to putrefactive amines, a rise in the volume of isovaleric acid and valeric acid content was also observed. These compounds are generated by the hydrolysis of protein in the putrefaction process of tissues and organs and cause an offensive odor. Further, the observed fall in amino acid volume also indicates the presence of bacteria that hydrolyze proteins and metabolize amino acids. These results reveal that the production of compounds related to putrefaction was promoted during ethanol abuse. Therefore, that putrefaction and the observed mouse death are considered to be due to ethanol abuse. The undesirable effects were repressed by the intake of live SN13T cells. Although it is still not understood what species and reactions are involved in the putrefaction with ethanol, further studies on the indigenous bacteria that belong to putative categories, such as the RF32 order, will be useful to confirm the mechanisms. 
In the present study, we demonstrated that alcohol-poisoning symptoms are improved by the oral administration of live SN13T cells but not by the administration of heat-killed cells. Based on these results, it is presumed that live SN13T cells or their collaboration with other intestinal bacteria may generate bioactive compounds. The bioactive compounds may cooperatively inhibit the synthesis of harmful products in the intestinal tract. Some research has shown that a change in the intestinal microbiota is involved in lifestyle and mental diseases [43,44]. We demonstrated in this study that the live SN13T cells are significant for maintaining intestinal microbiota balance and restoring from the symptoms of alcoholism.

\section{Materials and Methods}

\subsection{Culture Conditions of the LAB Strain}

De Man, Rogosa, and Sharpe (MRS) broth (Merck KGaA, Darmstadt, Germany) was used as a medium to cultivate for $\mathrm{Lb}$. plantarum SN13T. The bacterium was grown at $37^{\circ} \mathrm{C}$ overnight in the MRS broth. After cultivation, the bacterial cells were collected by centrifugation, resuspended, and diluted to the given concentration with sterilized water.

\subsection{Preparation of Diet for Mice}

As a diet with or without added ethanol, L10016 and L10015 (Research Diet, New Brunswick, NJ, USA) were prepared from Pre-Mix L10016A using ethanol or maltodextrin 42, respectively, according to the manufacturer's protocol, with a slight modification. To evaluate the survival rate of the mice, $6.6 \%$ $(v / v)$ ethanol at the final concentration or $118.27 \mathrm{~g} / \mathrm{L}$ maltodextrin 42 was added to Pre-Mix L10016A. If necessary, live SN13T cells (final $1-2 \times 10^{9} \mathrm{cfu} / \mathrm{mL}$ ) were added to the $\mathrm{L} 10016$ diet.

To analyze the microbiota or metabolites of the mice, $7.5 \%(v / v)$ ethanol at the final concentration or $134.40 \mathrm{~g} / \mathrm{L}$ maltodextrin 42 was added to prepare each diet. The live SN13T cell suspension (final $1-2 \times 10^{9} \mathrm{cfu} / \mathrm{mL}$ ) was added to the diet.

\subsection{Ethics Statement}

The animal experiment in the present study was conducted according to the "Guidelines for the Care and Use of Laboratory Animals" of Hiroshima University. All experimental procedures were approved by the "Committee of Research Facilities for Laboratory Animal Science of Hiroshima University" (Permit Numbers: A14-123 and A16-9, 19 November 2014, and 10 May 2016, respectively).

\subsection{Animal Experiment to Evaluate Survival Rate}

Male C57BL/6J specific pathogen free (SPF) mice (seven weeks of age) were purchased from Charles River Laboratories Japan, Inc. After the mice were kept for one week with a regular diet (MF, Oriental Yeast Co., Ltd., Tokyo, Japan), they were divided into four groups composed of five mice each in a plastic cage: Group I was fed only an L10015 diet without the administration of ethanol; group II was fed an L10016 diet with ethanol; group III was fed an L10016 diet with the simultaneous administration of ethanol and live SN13T cells; and group IV was fed an L10016 diet supplemented with ethanol and heat-killed SN13T cells. All mice were kept under conditions of $40 \%-60 \%$ humidity, $20-26{ }^{\circ} \mathrm{C}$, and a $12 \mathrm{~h}$ light $/ 12 \mathrm{~h}$ dark cycle. Since all of the diets contain sufficient water, the mice were not given any additional water; they had free access to the food. The diets were changed every day, and the amount of daily food intake by mice in each cage was monitored by weighing the remaining diet. The body weights of the mice were also recorded each week. The mice were distinguished by painting the tail of each a different color using felt-tip markers (Animal Marker, Muromachi Kikai Co., Ltd., Tokyo, Japan). After the rearing of mice, they were euthanized by inhalation of anesthesia with isoflurane. Feces from each cage was collected to analyze the fecal microbiota. 


\subsection{Animal Experiment to Analyze the Microbiota and Metabolites in the Intestine}

After being fed with the regular diet for one week, the male C57BL/6J SPF mice were divided into four groups: A, B, C, and D. The mice in each group were kept under the conditions described above. Prior to feeding with ethanol, the mice were kept for one week using the L10015 diet supplemented with (groups C and D) or without (groups A and B) live SN13T cells. After one week, the L10015 diet was changed to an L10016 diet in groups B and D. The diets were changed every day, and daily consumption was monitored. Two weeks after the start of the experiment, the mice were euthanized by the inhalation of anesthesia with isoflurane, and blood was collected from each mouse. The small and large intestines and the cecum were collected from each mouse to analyze the intestinal microbiota and cecal metabolites. Schemes summarizing the animal experiments are shown in Figure 6.

\section{(a) Animal experiment for survival analysis}

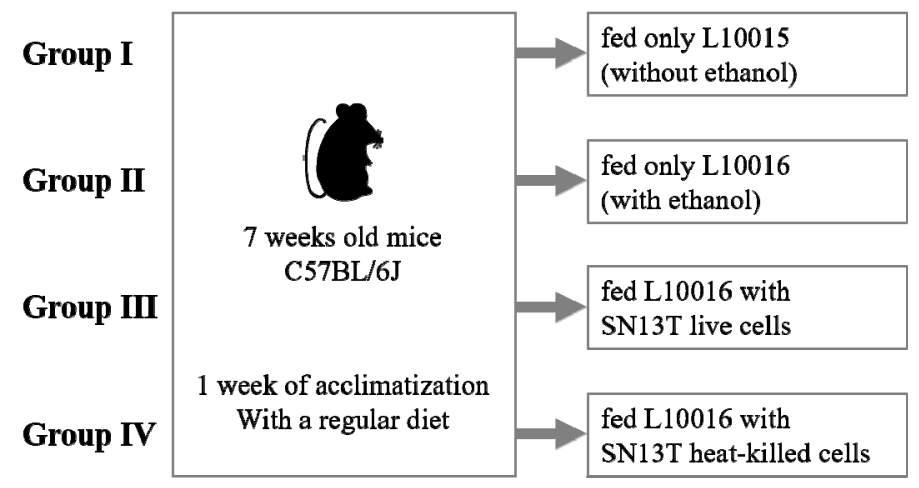

(b) Animal experiment for microflora and metabolite analyses

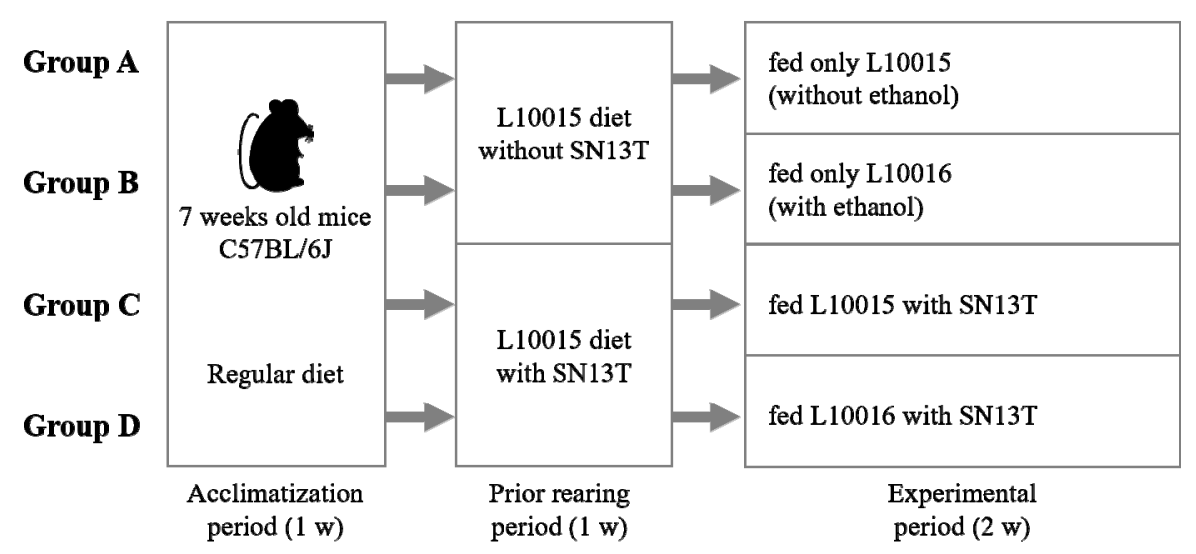

Figure 6. The outlines of animal experiments for survival analysis (a) and microbiota and metabolite analyses (b).

\subsection{Statistical Analyses}

Statistical analyses were conducted using the SPSS 17.0 software (SPSS Japan, Inc., Tokyo, Japan). The Tukey-Kramer test was applied for multiple comparisons of body weight and blood biochemical parameters. Mouse survival curves were plotted using the Kaplan-Meier method. The survival ratio between each group was analyzed using a log-rank test. 


\subsection{Analysis of the Fecal Microbiota Using the T-RFLP Method}

Mouse fecal microbiota were compared according to the T-RFLP method [45] with a slight modification [46]. The unit T-RF (terminal restriction fragment) is a just expedient, and the results were indicated as bacterial taxa designated OTU (operational taxonomic unit).

\subsection{Analysis of the Gut Microbiota via 165 rRNA Encoding Gene Sequencing}

Total DNA extraction from 200-500 mg of mouse gut contents was done using a Gencheck DNA extraction kit type S/F (FASMAC Co., Ltd., Kanagawa, Japan) according to the manufacturer's instructions. The $16 \mathrm{~S}$ rRNA-based microbiota analysis was conducted using the Illumina MiSeq sequencing platform (Illumina Inc., San Diego, CA, USA) using a 300 bp read length paired-end protocol. The V3-V4 regions of bacterial $16 \mathrm{~S}$ rRNA-encoding genes were PCR-amplified via TaKaRa Ex Taq HS (Takara Bio, Inc., Shiga, Japan) using the primers 1st_V3V4_F (5'-ACACTCTTTCCCTACACGACGC TCTTCCGATCTCCTACGGGNGGCWGCAG-3') and 1st_V3V4_R (5'-GTGACTGGAGTTCAGACGTG TGCTCTTCCGATCTGACTACHVGGGTATCTAATCC- $3^{\prime}$ ) under the following conditions: 2 min at 94 ${ }^{\circ} \mathrm{C}$ followed by 20 cycles of $30 \mathrm{~s}$ at $94{ }^{\circ} \mathrm{C}, 30 \mathrm{~s}$ at $50{ }^{\circ} \mathrm{C}$, and $30 \mathrm{~s}$ at $72{ }^{\circ} \mathrm{C}$, and finally a 5 min extension period at $72{ }^{\circ} \mathrm{C}$. The amplified fragments were purified using an Agencourt AMPure XP (Thermo Fisher Scientific, Waltham, MA, USA) according to the manufacturer's protocol. A 1/10 volume aliquot of the purified fragments was used for the second PCR reaction conducted with the primer set 2nd_F1 (5'-AATGATACGGCGACCACCGAGATCTACACNNNNNNNNACACTCTTTCCCTACACGACGC$\left.3^{\prime}\right)$ and 2nd_R1 (5'-CAAGCAGAAGACGGCATACGAGATNNNNNNNNGTGACTGGAGTTCAGAC GTGTG-3') using a TaKaRa Ex Taq HS under the following conditions (the underlined regions in each primer are index sequences designed to allow the analytical software to identify each sample): $2 \mathrm{~min}$ at $94{ }^{\circ} \mathrm{C}$ followed by eight cycles of $30 \mathrm{~s}$ at $94{ }^{\circ} \mathrm{C}, 30 \mathrm{~s}$ at $60^{\circ} \mathrm{C}$, and $30 \mathrm{~s}$ at $72{ }^{\circ} \mathrm{C}$, and finally a $5 \mathrm{~min}$ extension period at $72{ }^{\circ} \mathrm{C}$. The amplified fragments were also purified using an Agencourt AMPure XP. After sequencing analysis, the taxonomic assignments were done using the Quantitative Insights into Microbial Ecology (QIIME) pipeline [47].

\subsection{Sample Preparations for Metabolite Analysis of Bowel}

Metabolite analysis of the mouse bowel was performed by Human Metabolome Technologies, Inc. (Yamagata, Japan). To use liquid chromatography time-of-flight mass spectrometry (LC-TOFMS) in the analysis, a $50 \mathrm{mg}$ aliquot of the bowel sample from each group was resuspended into $1 \mathrm{~mL}$ of methanol containing $10 \mu \mathrm{M}$ Internal Standard Solution 1 (H3304-1002, Human Metabolome Technologies, Inc.). After centrifugation, a $200 \mu \mathrm{L}$ aliquot of the supernatant fluid was transferred to a new tube and dried in vacuo. Each dried sample was dissolved into $50 \%(v / v)$ isopropanol prior to the LC-TOFMS analysis. Meanwhile, for the capillary electrophoresis (CE)-TOFMS, a $50 \mathrm{mg}$ aliquot of the bowel contents in each group was resuspended into $450 \mu \mathrm{L}$ of Milli-Q water containing $200 \mu \mathrm{M}$ Internal Standard Solution 1. After centrifugation, a $400 \mu \mathrm{L}$ aliquot of the supernatant fluid was filtrated using an UltrafreeMC-PLHCC 250/pk for the metabolome analysis (5000 MWCO, Human Metabolome Technologies, Inc.) to remove proteins by centrifugation at $9100 \times \mathrm{g}$ for $1 \mathrm{~h}$ at $4{ }^{\circ} \mathrm{C}$. An $80 \mu \mathrm{L}$ aliquot of the filtrate was mixed with $20 \mu \mathrm{L}$ of Milli-Q water prior to the CE-TOFMS analysis.

\subsection{Analytical Conditions for LC-TOFMS and CE-TOFMS}

To analyze metabolites contained in the bowel using LC-TOFMS, the samples were applied on an Agilent 1200 series RRLC system SL (Agilent Technologies, Inc., Santa Clara, CA, USA) equipped with an MS system Agilent LC/MSD TOF (Agilent Technologies, Inc.) using an octadecylsilyl (ODS) column $(2 \times 50 \mathrm{~mm}, 2 \mu \mathrm{m})$. For CE-TOFMS analysis, the samples were applied on an Agilent CE-TOFMS system (Agilent Technologies, Inc.) using a fused silica capillary id $50 \mu \mathrm{m} \times 80 \mathrm{~mm}$. The analytical conditions are summarized in Table 3. The metabolites were identified by matching their times of migration and $m / z$ values with the annotation table of the library (Human Metabolome Technologies, Inc.). 
The resultant data were used for HCA, and the analysis was done using an unweighted pair-group method of analysis (UPGMA).

Table 3. Summary of the analytical conditions of liquid chromatography (LC)- and capillary electrophoresis time-of-flight mass spectrometry (CE-TOFMS) analyses used in this study.

\begin{tabular}{|c|c|c|}
\hline Conditions & Positive Mode & Negative Mode \\
\hline LC-TOFMS conditions & & \\
\hline LC system & \multicolumn{2}{|c|}{ Agilent 1200 series RRLC system SL } \\
\hline Column & \multicolumn{2}{|c|}{ ODS column, $2 \times 50 \mathrm{~mm}, 2 \mu \mathrm{m}$} \\
\hline MS system & \multicolumn{2}{|c|}{ Agilent LC/MSD TOF } \\
\hline Column temperature & \multicolumn{2}{|c|}{$40^{\circ} \mathrm{C}$} \\
\hline Mobile phase & \multicolumn{2}{|c|}{ A: $\mathrm{H}_{2} \mathrm{O} / 0.1 \% \mathrm{HCOOH}$} \\
\hline & \multicolumn{2}{|c|}{ B: Isopropano:Acetonitrile: $\mathrm{H}_{2} \mathrm{O}(63: 30: 5) / 0.1 \% \mathrm{HCOOH}, 2 \mathrm{mM} \mathrm{HCOONH}_{4}$} \\
\hline Flow rate & \multicolumn{2}{|c|}{$0.3 \mathrm{~mL} / \mathrm{min}$} \\
\hline Run time & \multicolumn{2}{|c|}{$20 \mathrm{~min}$} \\
\hline Post time & \multicolumn{2}{|c|}{$7.5 \mathrm{~min}$} \\
\hline Gradient condition & \multicolumn{2}{|c|}{$0-0.5 \min :$ B $1 \%, 0.5-13.5 \mathrm{~min}: \mathrm{B} 1 \%-100 \%, 13.5-20 \mathrm{~min}: \mathrm{B} 100 \%$} \\
\hline MS ionization mode & ESI positive & ESI negative \\
\hline MS nebulizer pressure & \multicolumn{2}{|c|}{40 psi } \\
\hline MS dry gas flow & \multicolumn{2}{|c|}{$10 \mathrm{~L} / \mathrm{min}$} \\
\hline $\begin{array}{l}\text { MS dry gas } \\
\text { temperature }\end{array}$ & \multicolumn{2}{|c|}{$350{ }^{\circ} \mathrm{C}$} \\
\hline MS capillary voltage & \multirow{2}{*}{\multicolumn{2}{|c|}{$\begin{array}{c}3500 \mathrm{~V} \\
\mathrm{~m} / \mathrm{z} 100-1700\end{array}$}} \\
\hline MS scan range & & \\
\hline $\begin{array}{l}\text { Sample injection } \\
\text { volume }\end{array}$ & \multicolumn{2}{|c|}{$1 \mu \mathrm{L}$} \\
\hline CE-TOFMS conditions & \multirow{2}{*}{\multicolumn{2}{|c|}{ Agilent CE-TOFMS system }} \\
\hline CE system & & \\
\hline Capillary & \multicolumn{2}{|c|}{ Fused silica capillary id $50 \mu \mathrm{m} \times 80 \mathrm{~cm}$} \\
\hline Run buffer & Cation Buffer Soln. (p/n: H3301-1001) & Anion Buffer Soln. (p/n: H3302-1021) \\
\hline Rinse buffer & Cation Buffer Soln. (p/n: H3301-1001) & Anion Buffer Soln. (p/n: H3302-1021) \\
\hline Sample injection & Pressure injection $50 \mathrm{mbar}, 10 \mathrm{~s}$ & Pressure injection $50 \mathrm{mbar}, 25 \mathrm{~s}$ \\
\hline CE voltage & Positive, $27 \mathrm{kV}$ & Positive, $30 \mathrm{kV}$ \\
\hline MS ionization & ESI positive & ESI negative \\
\hline MS capillary voltage & $4000 \mathrm{~V}$ & $3500 \mathrm{~V}$ \\
\hline MS scan range & \multicolumn{2}{|c|}{$m / z 50-1000$} \\
\hline Sheath liquid & \multicolumn{2}{|c|}{ HMT Sheath Liquid (p/n: H3301-1020) } \\
\hline
\end{tabular}

\section{Conclusions}

We demonstrate in the present study that the alcohol-poisoning symptom in mice is improved by the live SN13T cell or its collaboration with other intestinal bacteria. Our study indicates that probiotic bacteria which affect the microbiota may be an attractive target to produce healthcare supplements.

Supplementary Materials: Supplementary materials can be found at http://www.mdpi.com/1422-0067/21/5/1896/ s1.

Author Contributions: Conceptualization, M.N., M.M., and M.S.; methodology, M.N. and M.M.; validation, M.N.; visualization, M.N.; formal analysis, M.N.; investigation, M.N. and M.M.; resources, M.N., M.M., and M.S.; writing—original draft preparation, M.N., M.M., and M.S.; writing-review and editing, M.N., N.D., F.H., and M.S.; project administration, M.S.; funding acquisition, M.N. and M.S. All authors have read and agreed to the published version of the manuscript.

Funding: This work was partially supported by the JSPS Grants-in-Aid for Scientific Research, grant number 16K08294.

Acknowledgments: We thank the Analysis Center of Life Science, Hiroshima University, for the use of their facilities.

Conflicts of Interest: The authors declare no conflict of interest. 


\section{Abbreviations}

$\begin{array}{ll}\text { ADH } & \text { alcohol dehydrogenase } \\ \text { ALT } & \text { alanine aminotransferase } \\ \text { AST } & \text { aspartate transaminase } \\ \text { CE } & \text { capillary electrophoresis } \\ \text { FAO } & \text { Food and Agriculture Organization of the United Nations } \\ \gamma \text {-GTP } & \gamma \text {-glutamyl transpeptidase } \\ \text { HCA } & \text { hierarchical cluster analysis } \\ \text { IBD } & \text { inflammatory bowel disease } \\ \text { IgA } & \text { immunoglobulin A } \\ \text { LAB } & \text { lactic acid bacteria } \\ \text { Lb. } & \text { Lactobacillus } \\ \text { LC } & \text { liquid chromatography } \\ \text { MRS } & \text { de Man, Rogosa, and Sharpe } \\ \text { ODS } & \text { octadecylsilyl } \\ \text { OTU } & \text { operational taxonomic unit } \\ \text { QIIME } & \text { Quantitative Insights into Microbial Ecology } \\ \text { rDNA } & \text { ribosomal DNA } \\ \text { rRNA } & \text { ribosomal RNA } \\ \text { SPF } & \text { specific pathogen free } \\ \text { TOF-MS } & \text { time-of-flight mass spectrometry } \\ \text { T-RFLP } & \text { terminal restriction fragment length polymorphism } \\ \text { UPGMA } & \text { unweighted pair-group method of analysis } \\ & \end{array}$

\section{References}

1. Vallee, B.L. Alcohol in the western world. Sci. Am. 1998, 278, 80-85. [CrossRef]

2. The Social Issues Research Centre (SIRC). Social and cultural aspects of drinking. In A Report to the European Commission; SIRC: Oxford, UK, 1998.

3. Setshedi, M.; Wands, J.R.; de la Monte, S.M. Acetaldehyde adducts in alcoholic liver disease. Oxid. Med. Cell Longev. 2010, 3, 178-185. [CrossRef] [PubMed]

4. National Institute on Alcohol Abuse and Alcoholism (NIAAA). Alcohol metabolism: An update. In Alcohol Alert, No. 58; NIAAA: Rockville, MD, USA, 2002.

5. Rasineni, K.; Casey, C.A. Molecular mechanism of alcoholic fatty liver. Indian J. Pharmacol. 2012, 44, $299-303$. [CrossRef]

6. National Institute on Alcohol Abuse and Alcoholism (NIAAA). Alcohol and Nutrition. In Alcohol Alert, No. 22; NIAAA: Rockville, MD, USA, 1993.

7. Schuppan, D.; Afdhal, N.H. Liver cirrhosis. Lancet 2008, 8, 838-851. [CrossRef]

8. Sanders, M.E. Probiotics: Definition, source, selection, and uses. Clin. Infect. Dis. 2008, 46, S58-S61. [CrossRef] [PubMed]

9. Adolfsson, O.; Meydani, S.N.; Russell, R.M. Yogurt and gut function. Am. J. Clin. Nutr. 2004, 80, $245-256$. [CrossRef]

10. Cross, M.L.; Stevenson, L.M.; Gill, H.S. Anti-allergy properties of fermented foods: An important immunoregulatory mechanism of lactic acid bacteria? Int. Immunopharmacol. 2001, 1, 891-901. [CrossRef]

11. Heyman, M. Effect of lactic acid bacteria on diarrheal diseases. J. Am. Coll. Nutr. 2000, 19, 37S-146S. [CrossRef]

12. Meydani, S.N.; Ha, W.K. Immunologic effects of yogurt. Am. J. Clin. Nutr. 2000, 71, 861-872. [CrossRef]

13. Parvez, S.; Malik, K.A.; Ah Kang, S.; Kim, H.Y. Probiotics and their fermented food products are beneficial for health. J. Appl. Microbiol. 2006, 100, 1171-1185. [CrossRef]

14. Wang, Y.; Xu, N.; Xi, A.; Ahmed, Z.; Zhang, B.; Bai, X. Effects of Lactobacillus plantarum MA2 isolated from Tibet kefir on lipid metabolism and intestinal microflora of rats fed on high-cholesterol diet. Appl. Microbiol. Biotechnol. 2009, 84, 341-347. [CrossRef] [PubMed] 
15. Nguyen, T.D.; Kang, J.H.; Lee, M.S. Characterization of Lactobacillus plantarum PH04, a potential probiotic bacterium with cholesterol-lowering effects. Int. J. Food Microbiol. 2007, 113, 358-361. [CrossRef] [PubMed]

16. Liong, M.T.; Shah, N.P. Effects of a Lactobacillus casei synbiotic on serum lipoprotein, intestinal microflora, and organic acids in rats. J. Dairy Sci. 2006, 89, 1390-1399. [CrossRef]

17. Jin, H.; Higashikawa, F.; Noda, M.; Zhao, X.; Matoba, Y.; Kumagai, T.; Sugiyama, M. Establishment of an in vitro Peyer's patch cell culture system correlative to in vivo study using intestine and screening of lactic acid bacteria enhancing intestinal immunity. Biol. Pharm. Bull. 2010, 33, 289-293. [CrossRef]

18. Zhao, X.; Higashikawa, F.; Noda, M.; Kawamura, Y.; Matoba, Y.; Kumagai, T.; Sugiyama, M. The obesity and fatty liver are reduced by plant-derived Pediococcus pentosaceus LP28 in high fat diet-induced obese mice. PLOS ONE 2012, 7, e30696. [CrossRef]

19. Higashikawa, F.; Noda, M.; Awaya, T.; Danshiitsoodol, N.; Matoba, Y.; Kumagai, T.; Sugiyama, M. Antiobesity effect of Pediococcus pentosaceus LP28 on overweight subjects: A randomized, double-blind, placebo-controlled clinical trial. Eur. J. Clin. Nutr. 2016, 70, 582-587. [CrossRef]

20. Noda, M.; Sultana, N.; Hayashi, I.; Fukamachi, M.; Sugiyama, M. Exopolysaccharide produced by Lactobacillus paracasei IJH-SONE68 prevents and improves the picryl chloride-induced contact dermatitis. Molecules 2019, 24, 2970. [CrossRef]

21. Higashikawa, F.; Noda, M.; Awaya, T.; Nomura, K.; Oku, H.; Sugiyama, M. Improvement of constipation and liver function by plant-derived lactic acid bacteria: A double-blind, randomized trial. Nutrition 2010, 26, 367-374. [CrossRef]

22. Chadha, K.C.; Stadler, I.; Albini, B.; Nakeeb, S.M.; Thacore, H.R. Effect of alcohol on spleen cells and their functions in C57BL/6 mice. Alcohol 1991, 8, 481-485. [CrossRef]

23. Phillips, T.J.; Crabbe, J.C.; Metten, P.; Belknap, J.K. Localization of genes affecting alcohol drinking in mice. Alcohol Clin. Exp. Res. 1994, 18, 931-941. [CrossRef]

24. Belknap, J.K.; Mogil, J.S.; Helms, M.L.; Richards, S.P.; O’Toole, L.A.; Bergeson, S.E.; Buck, K.J. Localization to chromosome 10 of a locus influencing morphine analgesia in crosses derived from C57BL/6 and DBA/2 strains. Life Sci. 1995, 57, PL117-PL124. [CrossRef]

25. Grahame, N.J.; Phillips, T.J.; Burkhart-Kasch, S.; Cunningham, C.L. Intravenous cocaine self-administration in the C57BL/6J mouse. Pharmacol. Biochem. Behav. 1995, 51, 827-834. [CrossRef]

26. Food and Agriculture Organization of the United Nations (FAO) and World Health Organization (WHO). Toxicological evaluation of some extraction solvents and certain other substances. In FAO Nutrition Meetings Report Series No. 48A. 216; Ethanol; WHO/FOOD ADD/70.39; FAO/WHO: Geneva, Switzerland, 1970.

27. Canesso, M.C.C.; Lacerda, N.L.; Ferreira, C.M.; Gonçalves, J.L.; Almeida, D.; Gamba, C.; Cassali, G.; Pedroso, S.H.; Moreira, C.; Martins, F.S.; et al. Comparing the effects of acute alcohol consumption in germ-free and conventional mice: The role of the gut microbiota. BMC Microbiol. 2014, 14, 240.

28. Rao, R. Endotoxemia and gut barrier dysfunction in alcoholic liver disease. Hepatology 2009, 50, 638-644. [CrossRef]

29. Purohit, V.; Bode, J.C.; Bode, C.; Brenner, D.A.; Choudhry, M.A.; Hamilton, F.; Kang, Y.J.; Keshavarzian, A.; Rao, R.; Sartor, R.B.; et al. Alcohol, intestinal bacterial growth, intestinal permeability to endotoxin, and medical consequences: Summary of a symposium. Alcohol 2008, 42, 349-361. [CrossRef]

30. Forsyth, C.B.; Voigt, R.M.; Keshavarzian, A. Intestinal CYP2E1: A mediator of alcohol-induced gut leakiness. Redox Biol. 2014, 3, 40-46. [CrossRef]

31. Yoseph, B.P.; Breed, E.; Overgaard, C.E.; Ward, C.J.; Liang, Z.; Wagener, M.E.; Lexcen, D.R.; Lusczek, E.R.; Beilman, G.J.; Burd, E.M.; et al. Chronic alcohol ingestion increases mortality and organ injury in a murine model of septic peritonitis. PLoS ONE 2013, 8, e62792. [CrossRef] [PubMed]

32. Bollinger, R.R.; Barbas, A.S.; Bush, E.L.; Lin, S.S.; Parker, W. Biofilms in the large bowel suggest an apparent function of the human vermiform appendix. J. Theor. Biol. 2007, 249, 826-831. [CrossRef]

33. Sanders, N.L.; Bollinger, R.R.; Lee, R.; Thomas, S.; Parker, W. Appendectomy and Clostridium difficile colitis: Relationships revealed by clinical observations and immunology. World J. Gastroenterol. 2013, 19, 5607-5614. [CrossRef]

34. Masahata, K.; Umemoto, E.; Kayama, H.; Kotani, M.; Nakamura, S.; Kurakawa, T.; Kikuta, J.; Gotoh, K.; Motooka, D.; Sato, S.; et al. Generation of colonic IgA-secreting cells in the caecal patch. Nat. Commun. 2014, 5, 3704. [CrossRef] [PubMed] 
35. Smith, H.F.; Parker, W.; Kotzé, S.H.; Laurine, M. Morphological evolution of the mammalian cecum and cecal appendix. Comptes Rendus Palevol 2017, 16, 39-57. [CrossRef]

36. Collado, M.C.; Derrien, M.; Isolauri, E.; de Vos, W.M.; Salminen, S. Intestinal integrity and Akkermansia muciniphila, a mucin-degrading member of the intestinal microbiota present in infants, adults, and the elderly. Appl. Environ. Microbiol. 2007, 73, 7767-7770. [CrossRef]

37. Derrien, M.; Collado, M.C.; Ben-Amor, K.; Salminen, S.; de Vos, W.M. The mucin degrader Akkermansia muciniphila is an abundant resident of the human intestinal tract. Appl. Environ. Microbiol. 2008, 74, 1646-1648. [CrossRef] [PubMed]

38. Everard, A.; Belzer, C.; Geurts, L.; Ouwerkerk, J.P.; Druart, C.; Bindels, L.B.; Guiot, Y.; Derrien, M.; Muccioli, G.G.; Delzenne, N.M.; et al. Cross-talk between Akkermansia muciniphila and intestinal epithelium controls diet-induced obesity. Proc. Natl. Acad. Sci. USA 2013, 110, 9066-9071. [CrossRef] [PubMed]

39. Li, J.; Lin, S.; Vanhoutte, P.M.; Woo, C.W.; Xu, A. Akkermansia muciniphila protects against atherosclerosis by preventing metabolic endotoxemia-induced inflammation in Apoe-/-mice. Circulation 2016, 133, 2434-2446. [CrossRef] [PubMed]

40. Van Passel, M.W.; Kant, R.; Zoetendal, E.G.; Plugge, C.M.; Derrien, M.; Malfatti, S.A.; Chain, P.S.; Woyke, T.; Palva, A.; de Vos, W.M.; et al. The genome of Akkermansia muciniphila, a dedicated intestinal mucin degrader, and its use in exploring intestinal metagenomes. PLoS ONE 2011, 6, e16876. [CrossRef] [PubMed]

41. Grander, C.; Adolph, T.E.; Wieser, V.; Lowe, P.; Wrzosek, L.; Gyongyosi, B.; Ward, D.V.; Grabherr, F.; Gerner, R.R.; Pfister, A.; et al. Recovery of ethanol-induced Akkermansia muciniphila depletion ameliorates alcoholic liver disease. Gut 2018, 67, 891-901. [CrossRef]

42. Castro-Mejía, J.; Jakesevic, M.; Krych, Ł.; Nielsen, D.S.; Hansen, L.H.; Sondergaard, B.C.; Kvist, P.H.; Hansen, A.K.; Holm, T.L. Treatment with a monoclonal anti-IL-12p40 antibody induces substantial gut microbiota changes in an experimental colitis model. Gastroenterol. Res. Pract. 2016, 2016, 4953120. [CrossRef]

43. Shimokawa, C.; Obi, S.; Shibata, M.; Olia, A.; Imai, T.; Suzue, K.; Hisaeda, H. Suppression of obesity by an intestinal helminth through interactions with intestinal microbiota. Infect. Immun. 2019, 87, e00042-19. [CrossRef]

44. Liang, S.; Wu, X.; Jin, F. Gut-brain psychology: Rethinking psychology from the microbiota-gut-brain axis. Front. Integr. Neurosci. 2018, 12, 33. [CrossRef]

45. Liu, W.; Marsh, T.L.; Cheng, H.; Forney, L.J. Characterization of microbial diversity by determining terminal restriction fragment length polymorphism of genes encoding 16S rRNA. Appl. Environ. Microbiol. 1997, 63, 4516-4522. [CrossRef] [PubMed]

46. Nagashima, K.; Hisada, T.; Sato, M.; Mochizuki, J. Application of new primer-enzyme combinations to terminal restriction fragment length polymorphism profiling of bacterial populations in human feces. Appl. Environ. Microbiol. 2003, 69, 1251-1262. [CrossRef] [PubMed]

47. Caporaso, J.G.; Kuczynski, J.; Stombaugh, J.; Bittinger, K.; Bushman, F.D.; Costello, E.K.; Fierer, N.; Pena, A.G.; Goodrich, J.K.; Gordon, J.I.; et al. QIIME allows analysis of high-throughput community sequencing data. Nat. Methods 2010, 7, 335-336. [CrossRef] [PubMed]

(C) 2020 by the authors. Licensee MDPI, Basel, Switzerland. This article is an open access article distributed under the terms and conditions of the Creative Commons Attribution (CC BY) license (http://creativecommons.org/licenses/by/4.0/). 